\title{
Additional evidence for very large wing-span pterosaurs in the Wessex Formation (Early Cretaceous, Barremian) of southern England
}

\author{
David M. Martill ${ }^{\mathrm{a}}$ and Robert A. Coram ${ }^{\mathrm{b}}$ \\ ${ }^{a}$ School of Earth and Environmental Science, University of Portsmouth, Portsmouth PO1 3QL, UK \\ ${ }^{\mathrm{b} S c h o o l ~ o f ~ E a r t h ~ S c i e n c e s, ~ U n i v e r s i t y ~ o f ~ B r i s t o l, ~}$
}

\section{ABSTRACT}

A partial distal left metacarpal IV of a pterodactyloid pterosaur is notable for its size. The specimen, from the Early Cretaceous (Barremian) Wessex Formation exposed on the southwest coast of the Isle of Wight, southern England is identified as an ornithocheirid, perhaps close to the Ornithocheirus, Coloborhynchus, Caulkicephalus, Anhanguera complex. A morphometric analysis suggests an original wing span of approximately 5.6 metres. With an early Barremian age, this pterosaur would have been a giant for its time.

\section{Introduction}

Pterosaur remains are a rare, but significant component of the Wessex Formation (Wealden Group, Early Cretaceous, Barremian) vertebrate assemblage of the Isle of Wight in southern England (Hooley, 1913; Howse et al., 2001; Steel et al., 2005; Witton et al., 2009; Sweetman and Martill, 2010; Martill et al., 2011; Martill, 2015). The Wessex Formation pterosaur assemblage includes two valid named taxa; Istiodactylus latidens (Hooley, 1913) and Caulkicephalus trimicrodon Steel, Martill, Unwin and Winch, 2005, and some fragmentary remains that have satisfactorily been referred to the genus Coloborhynchus (Martill, 2015). Other material generally lacks diagnostic features at generic level and has been referred to the higher pterodactyloid clades Gnathosaurinae (Ctenochasmatoidea) and Neoazhdarchia (Azhdarchoidea) (Martill et al., 2011) or is regarded as undiagnostic (Howse et al., 2001). Amongst this material, mostly housed in the collections of Dinosaur Isle Museum, Sandown, Isle of Wight (accession numbers MIWG and IWCMS) and the Natural History Museum, London (accession numbers NHMUK) are some fragmentary specimens indicating large individuals. Some of these have previously been described on account of their large size, but the remains are very scrappy, and accurate estimates of their size proved problematic (Green, 1995; Martill et al., 1996). A newly discovered specimen (IWCMS 2016.270) comprises a large distal metacarpal IV that indicates a very large individual and is placed on record here.

\section{Locality and horizon.}

The new specimen was discovered in rock-fall debris on the beach about $1.5 \mathrm{~km}$ north west of Chilton Chine on the southwest coast of the Isle of Wight, where over ten kilometres of excellent 
exposures of the Wealden Group (both Wessex and Vectis formations: Barremian to lower Aptian) can be accessed. The section of coast between Chilton Chine and Sudmoor Point is known locally as The Undercliff (Fig. 1) and is well known to local fossil collectors as a rich source of vertebrate fossils, especially large dinosaurs (e.g. Martill and Naish, 2001; Naish et al., 2004; Sweetman, 2011). The cliffs at this locality comprise a sequence of red and variegated mudstones with channel sandstones representing a mud-dominated meander-belt river system (Stewart, 1978, 1981) punctuated by thin (10 $\mathrm{cm}$ to $1 \mathrm{~m}$ max) plant debris deposits representing large scale inundations in which plant and animal debris was washed into topographic lows on river floodplains (Sweetman and Insole, 2010). Vertebrate remains occur in three settings at this locality: as isolated or associated remains in plant debris beds; as rare, associated skeletons in overbank mudstones, and as worn and broken remains in channel lag deposits at the base of sandstone channels. Vertebrate trace fossils (footprints) also occur at some horizons, but none have yet been attributed to Pterosauria. The specimen is preserved in a matrix of a well-cemented pea-gravel of carbonate clasts of caliche origin (Fig. 2). This matrix is entirely consistent with derivation from intermittent channel fills in a plant debris bed overlying the Sudmoor Point Sandstone (L1 of Stewart, 1978, p. 35, fig. 7), a unit that is of lower Barremian age according to Batten (2011).

\section{Systematic palaeontology}

Pterosauria Kaup, 1834

Pterodactyloidea Plieninger, 1901

Ornithocheiroidea Seeley, 1891 sensu Unwin, 2003

Ornithocheiridae Seeley, 1870

Gen. et sp. indet.

Specimen. A single distal part of a left metacarpal IV of a pterodactyloid pterosaur cf. Ornithocheiridae. Accessioned in the collections of Dinosaur Isle Museum, Sandown specimen number IWCMS 2016.270 (Figs. 2-6; Table 1). Collected by R. A. Coram. Locality. Coast between Chilton Chine and Sudmoor Point, Isle of Wight. National Grid references SZ 4090782134 to SZ 3915882807 respectively.

Horizon and age. Most likely from a plant debris bed (L1 of Stewart 1978) immediately above the Sudmoor Point Sandstone Member, Wessex Formation. Early Cretaceous, Barremian. Plant debris bed (L1), variably along its outcrop contains a basal "pea-gravel" and pebble bed from which most of the vertebrate remains found loose on the beach in this area are derived (Sweetman and Insole 2010)

\subsection{Material}

IWCMS 2016.270 is a partial left metacarpal IV comprising the metacarpal portion of the metacarpophalangeal joint with a short length of distal diaphysis in a matrix of pisolitic caliche gritstone. There is some damage to the surface bone of the distal condyles that is probably post mortem - preburial erosion. There is a partial, geopetal infill of fine siderite cemented mudstone with a surface lining of drusy calcite. The remainder of the diaphysis is hollow. The specimen has been removed from the matrix to reveal the ventral surface. 


\subsection{Description.}

The specimen (Figs. 2,3) represents the distal portion, estimated to be approximately one third of the original length, of the left metacarpal IV of a pterodactyloid pterosaur. Some $84 \mathrm{~mm}$ are preserved. The distal diaphysis is irregularly broken to reveal a partially hollow interior (Fig. 3F). The cross sectional shape is oval with the anterior surface being somewhat flat and the posterior surface being shallowly depressed. The bone wall here is $3.2 \mathrm{~mm}$ thick on the dorsal margin, 1.5 $\mathrm{mm}$ thick on the anterior margin, $2 \mathrm{~mm}$ thick on the ventral margin and approximately $3.2 \mathrm{~mm}$ thick on the posterior margin. At the break the diaphysis is $32 \mathrm{~mm}$ dorso-ventrally and $14 \mathrm{~mm}$ antero-posteriorly. The articulatory surface for the metacarpophalangeal joint is considerably wider and higher than the diaphysis with a maximum height dorso-ventrally of $47 \mathrm{~mm}$, with perhaps a millimetre missing due to some abrasion damage. The width antero-posteriorly is 32.5 $\mathrm{mm}$ with some lost to abrasion. The distal face of the metacarpophalangeal articulatory surface is deeply sulcate but with a smoothly rounded centrally located bulge, describing a shallow 'wave form' in anterior view. An oval fossa, elongate in the long direction of the bone, is located adjacent to the dorsal articulatory process measuring $21 \mathrm{~mm}$ long $\times 12 \mathrm{~mm}$ wide and contains an oval pneumatic foramen at its proximal end measuring $7 \times 3 \mathrm{~mm}$ (Fig. $3 \mathrm{C}$ ). There is some damage in this region of the bone obscuring detail of the pneumatic foramen.

The articular portion expands slightly more to the dorsal margin distally giving a slightly asymmetrical flaring to the element seen in anterior aspect (Fig. 3B, D). In distal view, the articular condyles appear slightly angled with respect to the vertical axis of the diaphysis cross section, but there is no condylar skew or narrowing of the diaphysis (neck) as seen in the slender metacarpal IVs of Azhdarchidae and Dsungaripteridae (Martill et al., 2013) (Fig. 5).

\section{Dimensions.}

Despite its fragmentary nature, IWCMS 2016.270 is sufficiently well preserved to determine a number of accurate measurements, allowing a tentative reconstruction of the entire bone (Fig. 4, Table 1). The width and depth across the distal articulatory condylar surface (38 and $43 \mathrm{~mm}$ respectively) compares closely with those of previously described Ornithocheiridae (e.g. Kellner and Tomida, 2000; Elgin and Frey, 2011). It possesses a distal condyle that is gently expanded distally seen in caudal aspect, and the shaft immediately behind the condyle is not constricted, as it is in Azdarchoidea (Martill et al. 2013). A pteranodontian affinity is ruled out because of the lack of prominent offset of the condyle seen in Pteranodon (Martill et al. 2013, fig. 7E). Comparable, and complete, three-dimensionally preserved ornithocheirid metacarpals are figured by Wellnhofer (1991), Kellner and Tomida (2000) and Elgin and Frey (2011), all derived from the Early Cretaceous Santana Formation of northeast Brazil (Figs. 5, 6). In Santanadactylus araripensis (Figs $5 B, 6 D)$, in which the width and depth of the condyle are 33 and $32 \mathrm{~mm}$ respectively, the total length of the metacarpal is $232 \mathrm{~mm}$. Correspondingly, the length of metacarpal IV for IWCMS 2016.270 when complete is estimated at $280 \mathrm{~mm}$.

Frey and Martill (1994) described the ornithocheirid Arthurdactylus conandoylei from the Early Cretaceous Crato Formation of north east Brazil. This ornithocheirid pterosaur, although lacking any cranial remains, represents the most complete postcranial skeleton of an ornithocheirid yet described, and permits the ratios of the wing skeletal components to be established with 
certainty. The wing (humerus, radius, wrist, metacarpal IV, phalanges i-iv) has a straight length of $2.25 \mathrm{~m}$. Thus, allowing for a body width of $100 \mathrm{~mm}$, the total wingspan of Arthurdactylus conandoylei is $\sim 4.5 \mathrm{~m}$. In the wing of Arthurdactylus the metacarpal IV comprises approximately 10 percent of the single wing length. Thus the complete wing of IWCMS 2016.270 would likely measure about $2.75 \mathrm{~m}$, suggesting a total wingspan of around $5.6 \mathrm{~m}$. The specimen described here, although fragmentary, is evidence that pterosaurs were well on their way to achieving gigantic sizes perhaps 15 million years earlier than hitherto thought.

\section{$\underline{\text { Table of measurements here }}$}

\section{Discussion.}

A wing span estimated at $5.6 \mathrm{~m}$ is large for Early Cretaceous pterosaurs. Pterosaurs with wingspans in excess of $5 \mathrm{~m}$ have hitherto only been reported from Aptian/Albian or younger strata, with most of the largest examples (wingspans estimated at 9 or more metres) being restricted to the Late Cretaceous (Maastrichtian) (see Witton, 2013) for Azhdarchidae (Quetzalcoatlus, Hatzegopteryx, Arambourgiania Lawson, 1975; Buffetaut et al., 2003; Martill et al., 1998). The largest ornithcocheirids are reported from the Albian of Brazil (Tropeognathus Kellner et al., 2013) and the Albian of eastern England (Owen, 1859; Martill and Unwin, 2012), while a large ornithocheirid from the Aptian Crato Formation of Brazil has an estimated wingspan of $5.5 \mathrm{~m}$ (Cheng et al., 2018). An isolated ornithocheirid tooth from the Aptian of Tunisia was determined to come from an animal with a wingspan perhaps as large as $6 \mathrm{~m}$ by Martill et al. (2018). In China, ornithocheirid pterosaurs have been reported from the Barremian-Aptian age Jehol Group (Yixian and Jiufotang formations) of China (Wang and Lü, 2001). While the Barremian Haopterus only has a wingspan estimated at $1.35 \mathrm{~m}$, the wingspan of Liaoningopterus from the Lower Aptian Jiufotang Formation has been estimated to have been $\sim 5.0 \mathrm{~m}$ (Wang and Zhou, 2003).

Slightly older pterosaurs from the Berriasian to Late Valanginian Hastings Group of Sussex may also have achieved large sizes, but no material allowing reliable estimates of wing span has been recovered thus far (Martill et al., 2011). The presence of a large Barremian pterosaur in the Wessex Formation of the United Kingdom and in the Barremian of China shows that very large pterosaurs were already widespread early in the Cretaceous.

Although pterosaur remains are rare in the Wessex Formation of the Isle of Wight, their diversity (three named genera: Coloborhynchus, Caulkicephalus, Istiodactylus and an indeterminate azhdarchoid and ctenochasmatid) nevertheless suggests that they were an important part of the Wessex Formation ecosystem (Martill et al 2011). The taxonomic and morphological diversity suggests the pterosaurs were niche partitioned, with heterodont, fang-toothed ornithocheirids feeding on fishes, while isodont Istiodactylus may have been a meat scavenger (Witton, 2012; Martill, 2014). Probably edentulous azhdarchoids were also present in the Wealden Group, but are poorly known (Witton et al., 2009) and may have been terrestrial predators of small vertebrates (Witton and Naish, 2008). Evidence of small pterosaurs is rare, although approximately coeval pterosaur remains from the Wealden Group of Sussex do suggest smaller forms were present in southern England during the Early Cretaceous (Witton et al., 2009). The small azhdarchoid, Vectidraco daisymorrisae was described from the Aptian Atherfield Clay Formation that overlies the Wealden Group on the Isle of Wight (Naish et al. 2013). 


\section{Acknowledgements}

Thanks to Mr Gary Blackwell at Dinosaur Isle museum, Sandown, for preparing the specimen and to Mr M. Green of Brighstone, I.o.W. for access to Wessex Formation pterosaur specimens in his private collection. Thanks also to Lorna Steel and Sandra Chapman (NHMUK) for access to comparative material in the London collection, Alex Peaker at Dinosaur Isle, Sandown and Dino Frey (SMNK) for access to the Karlsruhe pterosaur collection. We are indebted to Dr Steve Sweetman for his helpful comments on an earlier version of this paper and especially for his in depth knowledge of Wealden Group stratigraphy. Thanks to the University of Portsmouth for funding this work. The two referees, N. Ibrahim and E. Frey, are thanked for their thoughtful commentary.

\section{References}

Averianov, A.O., 2010. The osteology of Azhdarcho lancicollis Nessov, 1984 (Pterosauria, Azhdarchidae) from the Late Cretaceous of Uzbekistan. Proceedings of the Zoological Institute RAS, 314, 264-317.

Batten, D.J., 2011. Wealden geology. In: Batten (Ed.) English Wealden fossils. Palaeontological Association, Field guides to Fossils Series, 14, 7-14.

Bennett, S.C., 2001. The osteology and functional morphology of the Late Cretaceous pterosaur Pteranodon. Part II. Size and functional morphology. Palaeontographica, A260, 113-153.

Buffetaut, E., Grogorescu, D., Csiki, Z., 2003. Giant azhdarchid pterosaurs from the terminal Cretaceous of Transylvania (wester Romania). In: Buffetaut, E., Mazin, J.-M. (Eds.) Evolution and palaeobiology of pterosaurs. Geological Society, London, Special Publications 217, 91104.

Cheng, X., Bantim, R.A.M., Sayão, J.M., Kellner, A.W.A., Wang, X. 2018. The largest flying reptile from the Crato Formation, Lower Cretaceous, Brazil. Historical Biology, DOI: 10.1080/08912963.2018.1491567

Codorniú, L., 2007. Osteología, Sistemática y Evolución de los reptiles voladores (Pterosauria) del Cretácico Inferior de San Luis, Argentina. PhD Thesis, Centro Regional Universitario Bariloche, Universidad del Comahue. 303 pp.

Eck, K., Elgin, R.A., Frey, E., 2011. On the osteology of Tapejara wellnhoferi Kellner 1989 and the first occurrence of a multiple specimen assemblage from the Santana Formation, Araripe Basin, NE-Brazil. Swiss Journal of Palaeontology, 130, 277-296.

Elgin, R.A., Frey, E., 2011. A new ornithocheirid, Barbosania gracilirostris gen. et sp. nov. (Pterosauria, Pterodactyloidea) from the Santana Formation (Cretaceous) of NE Brazil. Swiss Journal of Palaeontology 130, 259-275. doi:10.1007/s13358-011-0017-4 
Frey, E., Martill, D. M., 1994. A new pterosaur from the Crato Formation (Lower Cretaceous, Aptian) of Brazil. Neues Jahrbuch für Paläontologie, Abhandlungen 194, 379-412.

Galton, P.M., 1981. A rhamphorhynchoid pterosaur from the Upper Jurassic of North America. Journal of Paleontology, 55, 1117-1122.

Green, M., 1995. New pterosaur remains from the Isle of Wight. The Geological Society of the Isle of Wight, Newsletter 1, 18-23.

Hooley, R.W., 1913. On the skeleton of Ornithodesmus latidens: an ornithosaur from the Wealden Shales of Atherfield (Isle of Wight). Quarterly Journal of the Geological Society of London 69, $372-421$.

Howse, S.C B., Milner, A.R., Martill, D. M., 2001. Pterosaurs. In: Martill, D.M., Naish, D. (eds.), Dinosaurs of the Isle of Wight. Palaeontological Association Field Guide to Fossils, 10, London: 324-355.

Kaup, J., 1834. Versuch einer Eintheilung der Saugethiere in 6 Stämme und der Amphibien in 6 Ordnungen. Isis 3, 311-315.

Kellner, A.W.A., Campos, D.A., Sayão, J.M., Saraiva, A.A.F., Rodrigues, T., Oliveira, G., Cruz, L.A., Costa, F.R., Silva H.P., Ferreira, J.S., 2013. The largest flying reptile from Gondwana: a new specimen of Tropeognathus cf. T. mesembrinus Wellnhofer, 1987 (Pterodactyloidea, Anhangueridae) and other large pterosaurs from the Romualdo Formation, Lower Cretaceous, Brazil. Anais da Academia Brasileira de Ciências 85, 113-135.

Kellner, A.W.A., Tomida, Y., 2000. Description of a new species of Anhangueridae (Pterodactyloidea) with comments on the pterosaur fauna from the Santana Formation (Aptian-Albian), north eastern Brazil. National Science Museum Monographs 17, 1-135.

Lawson, D.A. 1975. Pterosaur from the latest Cretaceous of West Texas: discovery of the largest flying creature. Science 187, 947-948.

Lü, J., Azuma, Y., Dong, Z., Barsbold, R., Kobayashi Y., Lee, Y., 2009. New material of dsungaripterid pterosaurs (Pterosauria: Pterodactyloidea) from western Mongolia and its palaeoecological implications. Geological Magazine 146, 690-700. doi:10.1017/S0016756809006414

Martill, D.M., 2014. A functional odontoid in the dentary of the Early Cretaceous pterosaur Istiodactylus latidens: Implications for feeding. Cretaceous Research 47, 56-65

Martill, D.M., 2015. First occurrence of the pterosaur Coloborhynchus (Pterosauria, Ornithocheiridae) from the Wessex Formation (Lower Cretaceous) of the Isle of Wight, England. Proceedings of the Geologists' Association 126, 377-380. 
Martill, D.M., Frey, E., Green, M., Green, M.E., 1996. Giant pterosaurs from the Lower Cretaceous of the Isle of Wight, UK. Neues Jahrbuch für Geologie und Paläontologie, Monatsefte, 1996, 672-683.

Martill, D.M., Frey, E., Sadaqah, R.M., Khoury, H.N., 1998. Discovery of the holotype of the giant pterosaur Titanopteryx philadelphiae Arambourg 1959, and the status of Arambourgiania and Quetzalcoatlus. Neues Jahrbuch für Geologie und Paläontologie, Abhandlungen 207, 5776.

Martill, D.M., Ibrahim, N., Bouaziz, S. 2018. A giant pterosaur in the Early Cretaceous (Albian) of Tunisia. Journal of African Earth Sciences 147, 331-337. DOI:

10.1016/j.jafrearsci.2018.05.008

Martill, D.M., Naish, D. 2001. Dinosaurs of the Isle of Wight. The Palaeontological Association, Field Guides to Fossils, 10, 433 pp.

Martill, D.M., O’Sullivan, M., Newman, C., 2013. A possible azhdarchid pterosaur (Pterosauria, Azhdarchidae) in the Durlston Formation (Early Cretaceous, Berriasian) of southern England. Cretaceous Research 43, 26-39.

Martill, D.M., Sweetman, S.C., Witton, M.P., 2011. Pterosaurs. In: Batten, D.J. (Ed.) English Wealden fossils. Palaeontological Association, Field guides to Fossils Series, 14, 370-390.

Martill, D. M., Unwin, D.M., 2012. The World's largest toothed pterosaur, NHMUK R481, an incomplete rostrum of Coloborhynchus capito (Seeley, 1870) from the Cambridge Greensand of England. Cretaceous Research 34, 1-9.

Naish, D., Martill, D.M., Cooper, D., Stevens, K.A., 2004. Europe's largest dinosaur? A giant brachiosaurid cervical vertebra from the Wessex Formation (Early Cretaceous) of southern England. Cretaceous Research 25, 787-795.

Naish, D., Simpson, M., Dyke, G., 2013. A new small-Bodied azhdarchoid pterosaur from the Lower Cretaceous of England and its implications for pterosaur anatomy, diversity and phylogeny. PLoS ONE. 8 (3): e58451. doi:10.1371/journal.pone.0058451

Owen, R., 1859. On remains of new and gigantic species of pterodactyle (Pter. Fittoni and Pter. Sedgwickii) from the Upper Greensand, near Cambridge. Report of the British Association for the Advancement of Science, Leeds, 1858, 98-103.

Plieninger, F., 1901. Beiträge zur Kenntnis der Flugsaurier. Palaeontographica 48, 65-90.

Seeley, H.G., 1870. The Ornithosauria. An elementary study of the bones of pterodactyls, made from fossil remains found in the Cambridge Upper Greensand, and arranged in the Woodwardian Museum of the University of Cambridge. Deighton, Bell \& Co., Cambridge xii + $135 \mathrm{pp}$. 
Seeley, H.G., 1891. On the shoulder girdle in Cretaceous Ornithosauria. Annals and Magazine of Natural History 6 (7), 438-445.

Steel, L., Martill, D.M., Unwin, D.M., Winch, J.D., 2005. A new pterodactyloid pterosaur from the Wessex Formation (Lower Cretaceous) of the Isle of Wight. Cretaceous Research 26, 686698.

Stewart, D.J., 1978. The Sedimentology and palaeoenvironment of the Wealden Group of the Isle of Wight, Southern England. Unpublished Ph.D. thesis, University of Portsmouth, 346 p. + appendices.

Stewart, D.J., 1981. A meander belt sandstone from the Lower Cretaceous Wealden Group of southern England. Sedimentology 28, 1-20.

Sweetman, S.C., 2011. The Wealden of the Isle of Wight. In: Batten, D.J. (ed.) English Wealden Fossil. Palaeontological Association, Field Guides to Fossils, No. 14, 52-78.

Sweetman, S.C., Insole, A.N., 2010. The plant debris beds of the Early Cretaceous (Barremian) Wessex Formation of the Isle of Wight, southern England: their genesis and palaeontological significance. Palaeogeography, Palaeoclimatology, Palaeoecology, 292, 409-424.

Sweetman, S.C., Martill, D.M., 2010. Pterosaurs of the Wessex Formation (Early Cretaceous, Barremian) of the Isle of Wight, southern England: a review with new data. Journal of Iberian Geology 36, 225-242.

Unwin, D.M., 2003. On the phylogeny and evolutionary history of pterosaurs. In: Buffetaut, E., Mazin, J.-M. (Eds.), Evolution and Palaeobiology of Pterosaurs. Geological Society of London, Special Publications, 217, 139-190.

Wang, X. and Lü, J. 2001. Discovery of a pterodactyloid pterosaur from the Yixian Formation of western Liaoning, China. Chinese Science Bulletin 45(12), 447-454.

Wang, X.-L., Zhou Z.-H. 2003. Two new pterodactyloid pterosaurs from the Early Cretaceous Jiufotang Formation of Western Liaoning, China. Vertebrata PalAsiatica 41(1), 34-41.

Wellnhofer, P., 1978. Pterosauria. Handbuch der Paläoherpetologie 19, ix +82 pp.

Wellnhofer, P., 1991. Weitere Pterosaurierfunde aus der Santana-Formation (Apt) der Chapada do Araripe, Brasilien. Palaeontographica A 215, 43-101.

Witton, M.P., 2012. New insights into the skull of Istiodactylus latidens (Ornithocheiroidea, Pterodactyloidea). PLoS ONE 7(3): e33170. doi:10.1371/journal.pone.0033170 Witton, M.P., 2013. Pterosaurs: natural history and evolution. Princeton University Press, 291 pp. Witton, M. P., Martill, D.M., Green, M., 2009. On pterodactyloid diversity in the British Wealden (Lower Cretaceous) and a reappraisal of "Palaeornis" cliftii Mantell, 1844. Cretaceous Research 30, 676-686. 
Witton, M.P., Naish, D., 2008. A reappraisal of azhdarchid pterosaur functional morphology and paleoecology. PLoS ONE 3(5) e2271: doi:10.1371/journal.pone.0002271

Young, C.C., 1964. On a new pterosaurian from Sinkiang, China. Vertebrata Palasiatica, 8, 221-255. 
Figures

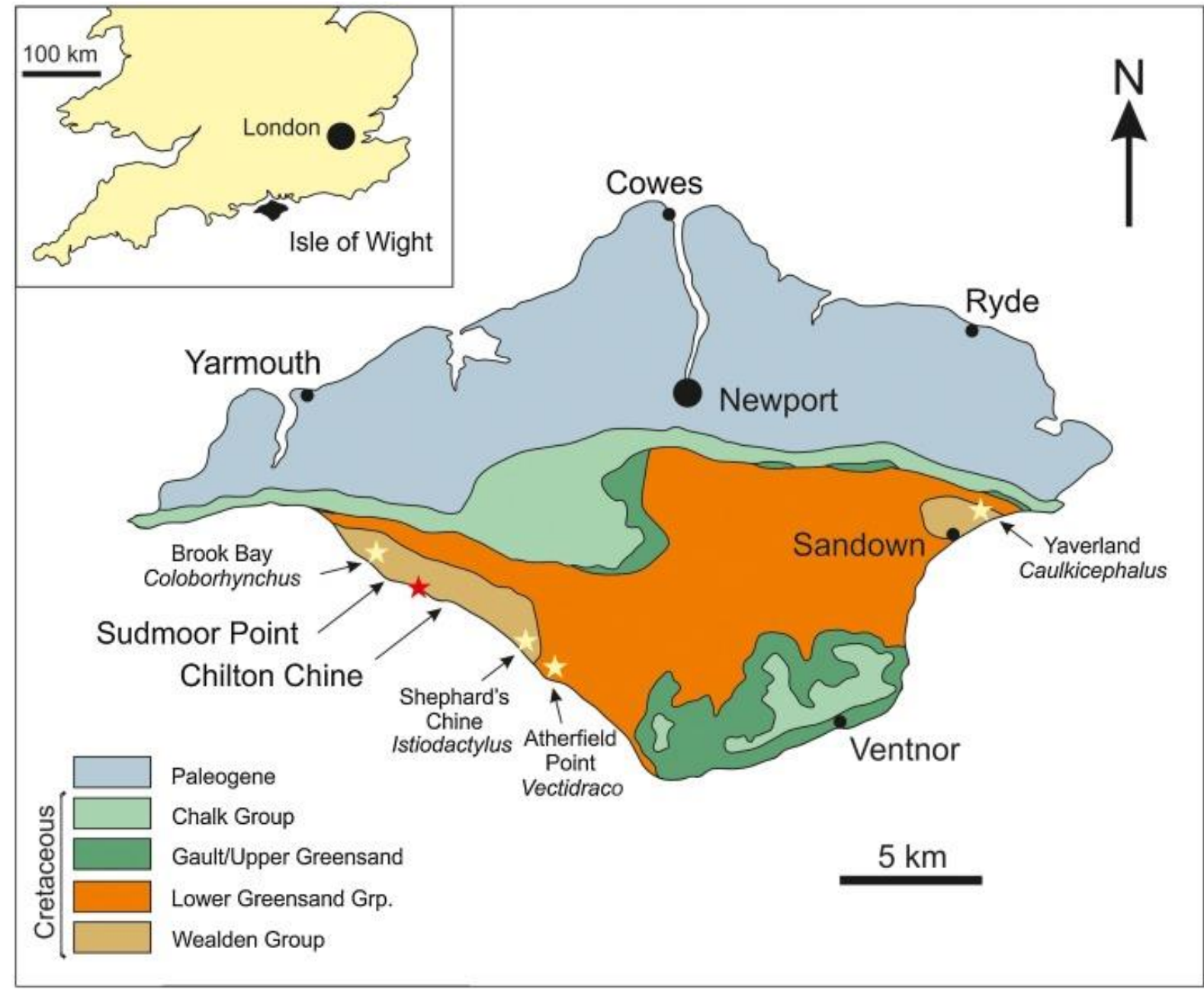

Fig. 1. Simplified geological map of the Isle of Wight with the outcrop of the Wessex Formation indicated. The discovery site of the specimen described here is between Chilton Chine and Sudmoor Point (large arrows), and other pterosaur localities are indicated with small arrows and the genus given. 


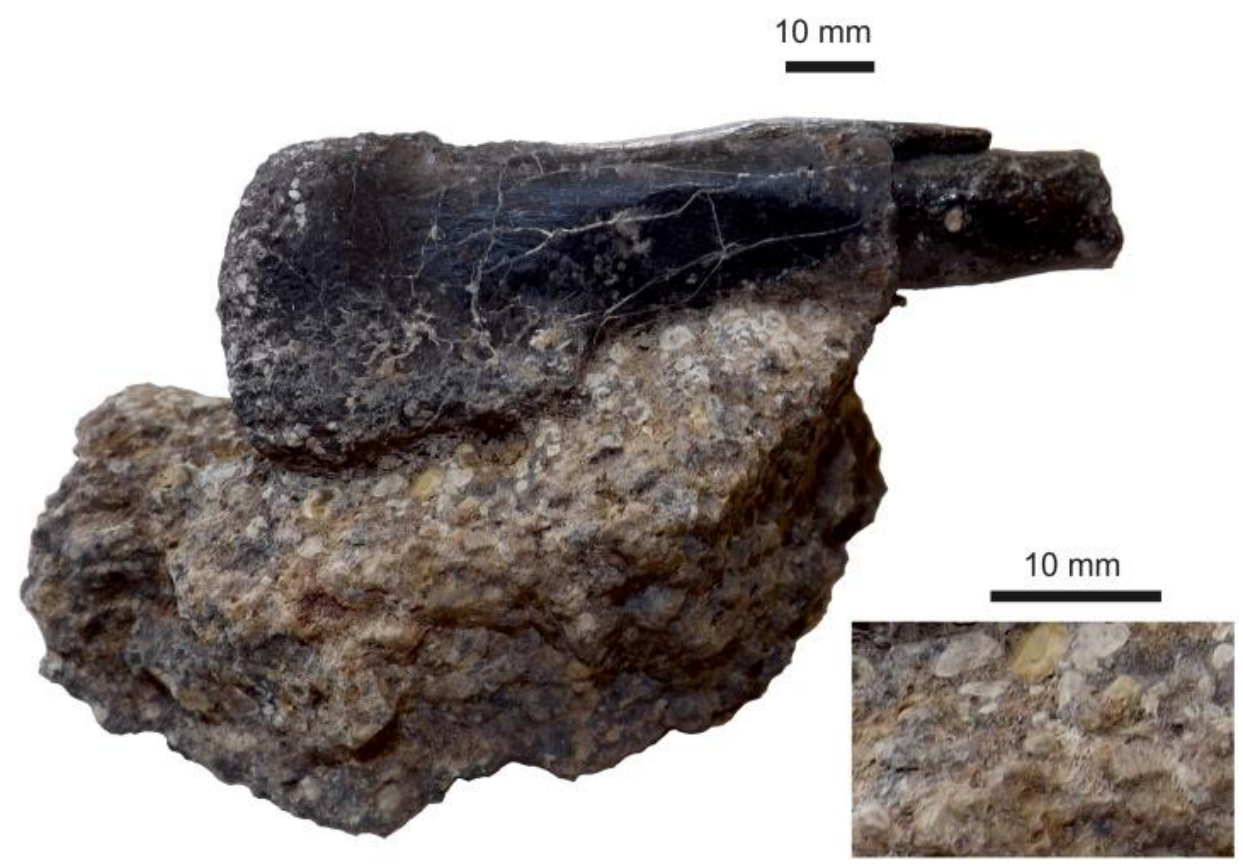

Fig. 2. New pterosaur metacarpal IV specimen viewed in dorsal view in caliche grit matrix typical of Wessex Formation fluvial channel deposits. Inset shows detail of caliche clasts. 
A
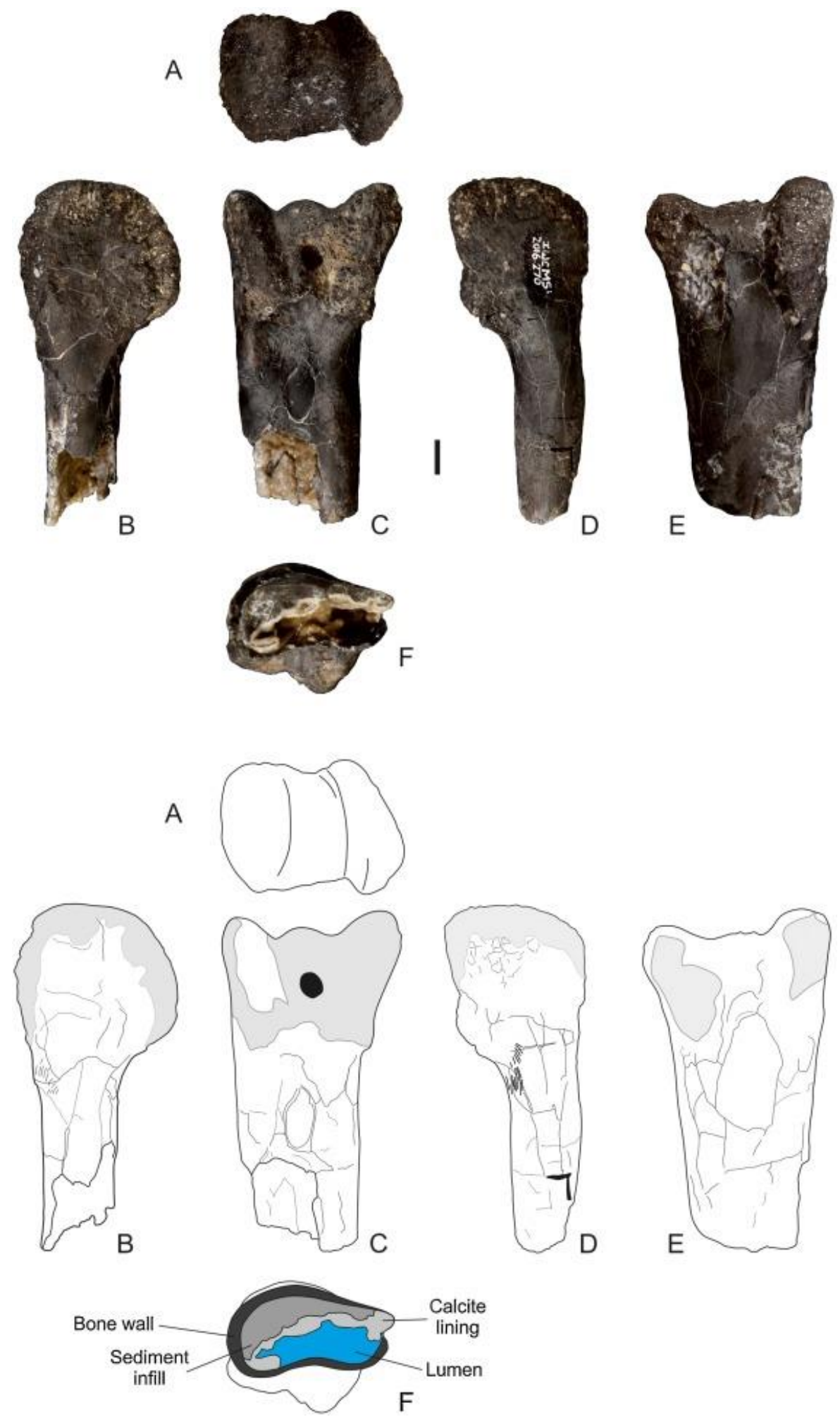

Fig. 3. New pterosaur specimen. Distal end of left metacarpal IV from the Wessex Formation of the southwest Isle of Wight after complete preparation from the matrix, accession number IWCMS 2016.270. Seen in distal (a), ventral (B), caudal (C), dorsal (D), cranial (E), proximal (F) views. Below interpretive drawings of the same views. Scale bar $=10 \mathrm{~mm}$. 

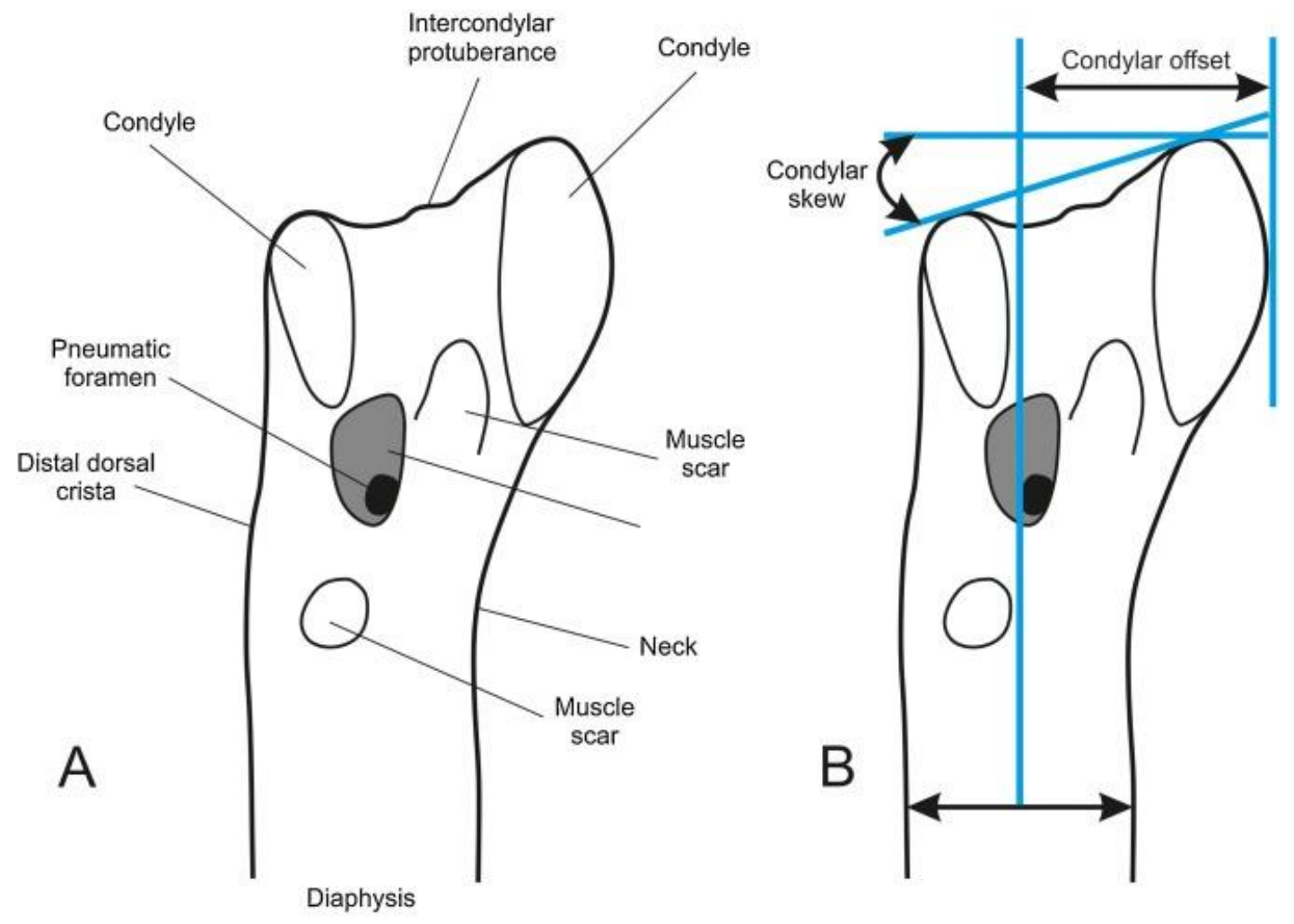

Fig. 4. Interpretative drawing of specimen IWCMS 2016.270 with morphology highlighted. seen in caudal view. 

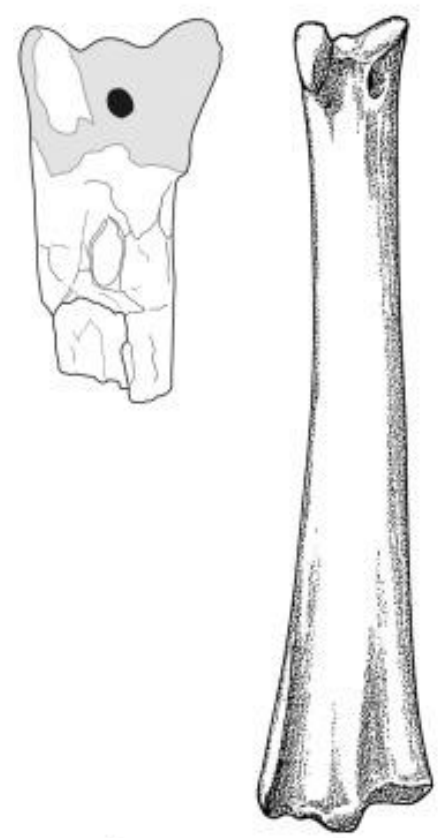

A

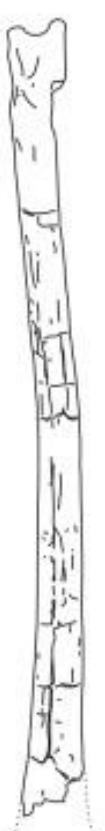

$\mathrm{H}$

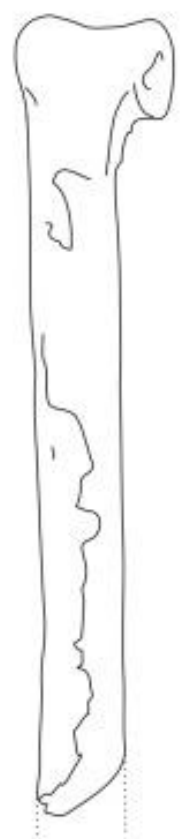

।

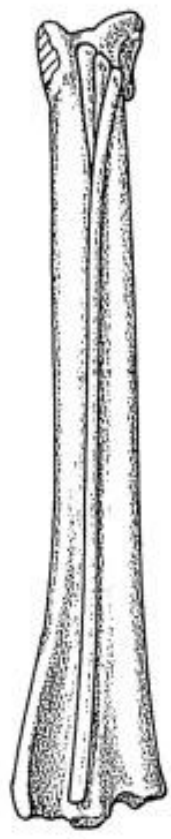

$\mathrm{C}$

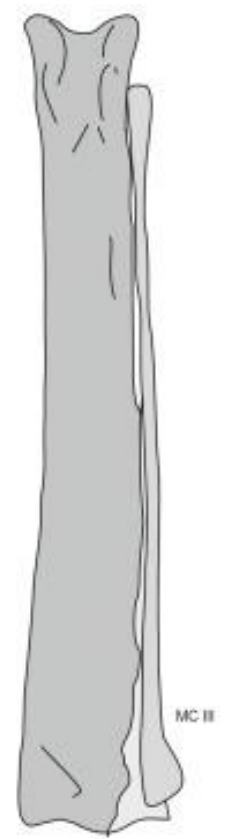

D

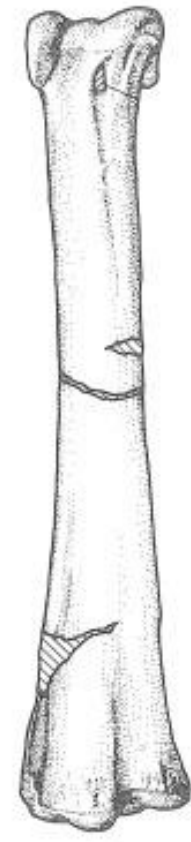

E
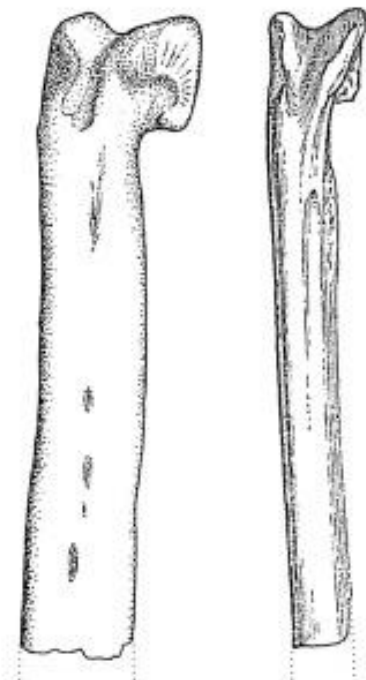

G
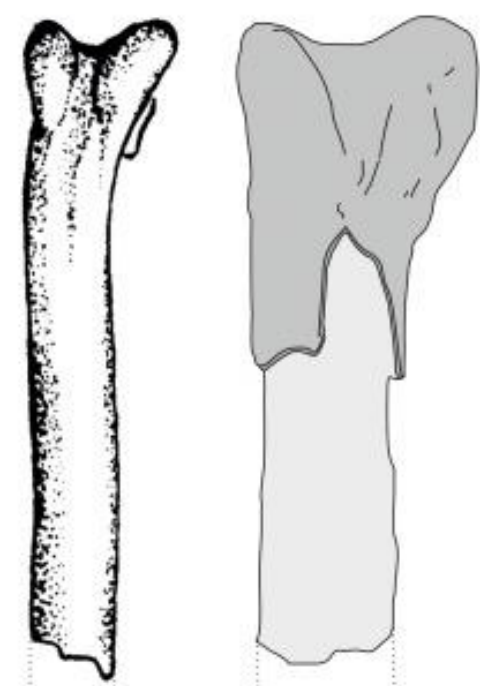

$\mathrm{K}$

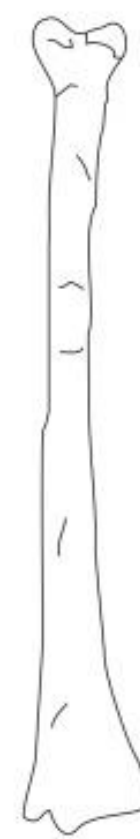

L

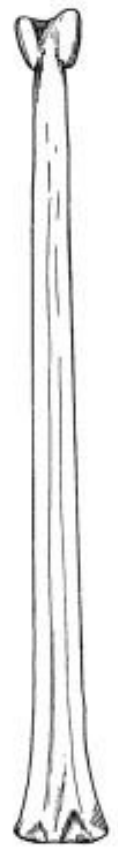

$\mathrm{M}$

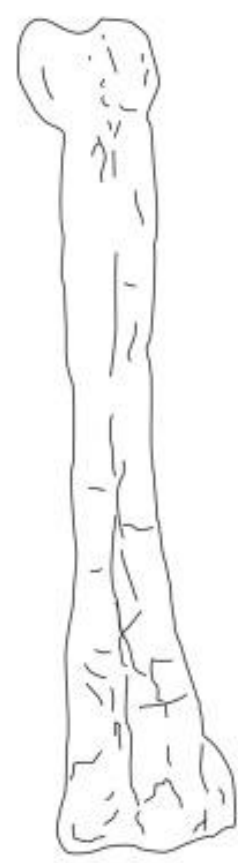

$\mathrm{N}$

Fig. 5. Morphology of pterosaur metacarpals IV. A, IWCMS 2016.270 distal portion of left metacarpal IV: B, Santanadactylus araripensis (after Wellnhofer, 1991, fig. 39c); C, Santanadactylus pricei (after Wellnhofer, 1991, fig. 31a); D, Barbosania gracilirostris (drawn from holotype after Elgin and Frey 2011); E, Coloborhynchus piscator (after Kellner and Tomida, 2000; reversed); F, Pteranodon (after Bennett, 2001; flipped); G, Dsungaripterus weii (holotype; after Young, 1964, fig. 4c); H, Dsungaripterus weii (GIN125/1010-2, traced from Lü et al., 2009, fig. 4d); I, Tupuxuara longicristata (traced and reversed from Wellnhofer, 1991); J, Dermodactylus montanus (after Galton, 1981, fig. 2q; rotated); K, Azhdarcho lancicollis (after Averianov, 2010, fig. 30a; flipped); L, Tapejara wellnhoferi (juvenile) (after Eck et al., 2011, fig. 3a); M, Cycnorhamphus suevicus (after Wellnhofer, 1978); N, Pterodaustro guinazui (after Codorniú, PhD thesis). Not to scale. 
A

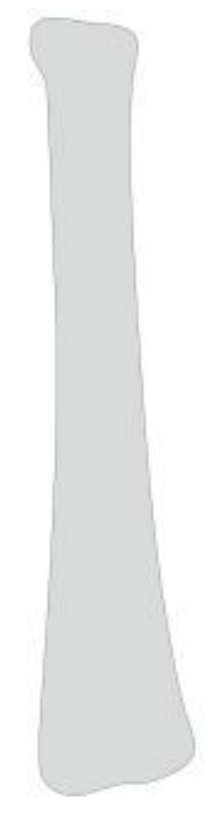

Barbosenia graciliostris from Elin ard Frey, 2011
B

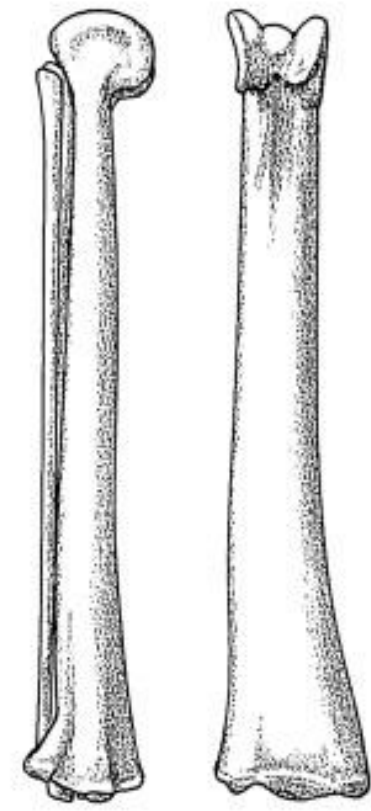
Sentanadoctylus prices
C

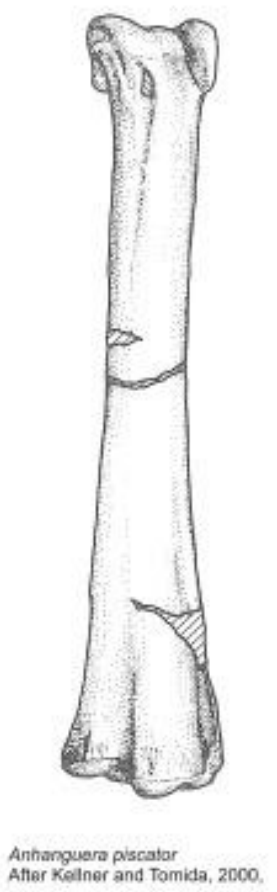

D

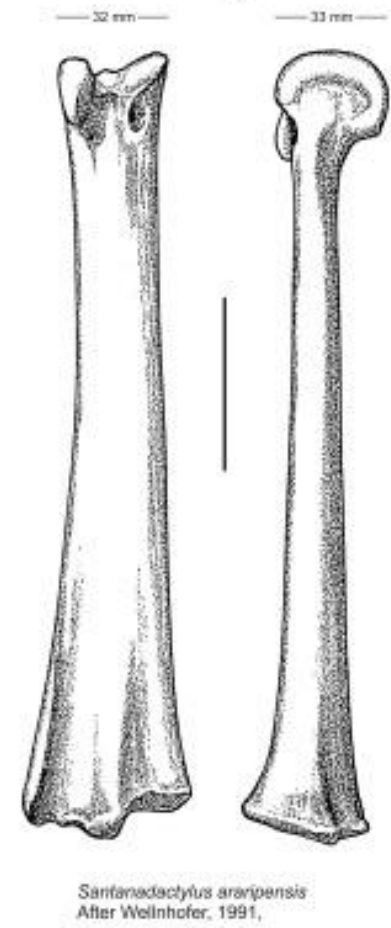

$\mathrm{E}$

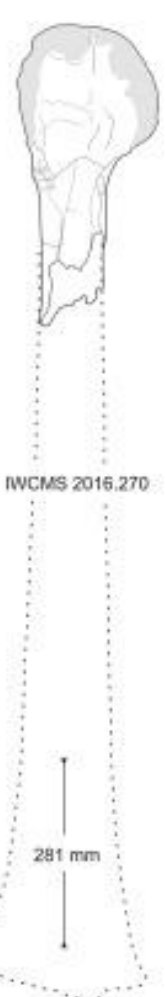

Fig. 6. Ornithocheirid metacarpals from the species (A) Barbosania gracilirostris, (B) Anhanguera piscator, (C) Santanadactylus pricei, (D) Santanadactylus araripensis and E, IWCMS 2016.270 showing consistency of form across ornithocheirid taxa. The scale bar is correct for Santanadactylus araripensis. All other taxa are scaled to the same length by using the drag function in Corel draw. $E$ is to the same scale and the length of the metacarpal established using the drag function applied to D. 
Table 1. Selected measurements for IWCMS 2016.270

\begin{tabular}{|l|c|}
\hline \multicolumn{1}{|c|}{ Measurement } & Value in $\mathrm{mm}$. \\
\hline $\begin{array}{l}\text { Maximum diameter of diaphysis behind } \\
\text { condyle }\end{array}$ & 32 \\
\hline $\begin{array}{l}\text { Minimum diameter of diaphysis behind } \\
\text { condyle }\end{array}$ & 20 \\
\hline Maximum width of condyle & 38 \\
\hline $\begin{array}{l}\text { Height of articulatory surface of } \\
\text { metacarpohalangeal joint }\end{array}$ & 32.5 \\
\hline Minimum width of condyle & 43 \\
\hline Maximum depth of condyle & 21 \\
\hline Length of oval depression on anterior fascia & 84 \\
\hline Maximum length of specimen as preserved & 3.2 \\
\hline Maximum bone thickness at proximal end & 1.5 \\
\hline Minimum bone thickness at proximal end & \\
\hline
\end{tabular}

